Article

\title{
Sustainable Strategies for the Exploitation of End-of-Life Permanent Magnets
}

\author{
Alessandro Becci (D), Francesca Beolchini (D) and Alessia Amato*(D) \\ Department of Life and Environmental Sciences (DiSVA), Università Politecnica of Marche, Via Brecce Bianche, \\ 60131 Ancona, Italy; a.becci@pm.univpm.it (A.B.); f.beolchini@univpm.it (F.B.) \\ * Correspondence: a.amato@univpm.it
}

\begin{abstract}
The growing production of green technologies (such as electric vehicles and systems for renewable electricity production, e.g., wind turbine) is increasing the rare earth element (REE) demands. These metals are considered critical for Europe for their economic relevance and the supply risk. The end-of-life permanent magnets are considered a potential secondary resource of REEs thanks to their content of neodymium (Nd), praseodymium (Pr) or dysprosium (Dy). The scientific literature reports many techniques for permanent magnet recovery. This work used a life cycle assessment (LCA) to identify the most sustainable choice, suggesting the possible improvements to reduce the environmental load. Three different processes are considered: two hydrometallurgical treatments (the first one with $\mathrm{HCl}$ and the other one with solid-state chlorination), and a pyrometallurgical technique. The present paper aims to push the stakeholders towards the implementation of sustainable processes for end-of-life permanent magnet exploitation at industrial scale.
\end{abstract}

Keywords: permanent magnet; rare earth oxides; recycling; circular economy; environmental sustainability; life cycle assessment

Citation: Becci, A.; Beolchini, F.;

Amato, A. Sustainable Strategies for the Exploitation of End-of-Life

Permanent Magnets. Processes 2021, 9 , 857. https://doi.org/10.3390/ pr9050857

Academic Editors: Luigi Piga, Nicolò

Maria Ippolito and

Valentina Innocenzi

Received: 30 April 2021

Accepted: 11 May 2021

Published: 13 May 2021

Publisher's Note: MDPI stays neutral with regard to jurisdictional claims in published maps and institutional affiliations.

\section{Introduction}

The objective of the European Union is to achieve the climate neutrality. Between 1990 and 2018, the European greenhouse emissions are reduced by $23 \%$ despite an industrial growth of $61 \%$. The aim is to reduce the greenhouse emissions by $60 \%$ by 2050 [1]. More than $75 \%$ of the European greenhouse gas emissions are due to the energy production and extraction/processing of materials, fuel and food [1,2]. The main ways to reduce these sector impacts are the increase of energy production by renewable resources (mainly offshore wind) and the use of hybrid and electric cars to reduce the fossil fuel dependence, with the reduction of $90 \%$ of transport emissions within 2050 [1].

The world market of hybrid/electric cars and offshore wind turbines is predicted to reach approximatively 150 million vehicles and 2500 GW, respectively, within 2050 [3]. These green technologies require the use of permanent magnets, such as ferrite, alnico, samarium-cobalt and neodymium-iron-boron (Nd-Fe-B) [4]. Permanent magnets generate electric and mechanical energy by a magnetic field, without the need of electric power [3]. $\mathrm{Nd}-\mathrm{Fe}-\mathrm{B}$ magnets are considered as the strongest and the best permanent magnet available since 1984 to today [5-7]. These magnets are the third generation of permanent magnets and they can produce a maximum electricity power of $512 \mathrm{~kJ} / \mathrm{m}^{3}[5,6,8]$. The main problem of these magnets is the low resistance to high temperatures (Curie temperature stands around $312^{\circ} \mathrm{C}$ ). To increase both the temperature stability and the corrosion resistant, cobalt (Co), praseodymium $(\mathrm{Pr})$ and dysprosium $(\mathrm{Dy})$ are integrated within the material $[4,6]$. It is estimated that we will need around 150,000 tons and 1-2 million tons of permanent magnets to cover the future demand of electric vehicles and wind turbines, respectively [3]. Nd-Fe-B magnets are composed of $30 \mathrm{wt} \%$ of rare earth elements (REEs) and around 1300 tons $(16 \%$ of the REE produced) were used for wind turbines in 2010 [5,9]. The REE production is considered critical for European Union, since around $90 \%$ of these elements is mined in 
China, that produces around 105,000 tons/year of REE. The unique properties of REE make them irreplaceable $[10,11]$. The production of one ton of REE generates around $1000 \mathrm{~m}^{3}$ of waste gas (containing $\mathrm{CO}_{2}, \mathrm{SO}_{2}$ and $\mathrm{HF}$ ), $75 \mathrm{~m}^{3}$ of acid wastewater and 1 ton of radioactive waste (mainly thorium and uranium) [12,13]. For this reason, companies and countries start to study and develop programs for the exploitation, substitution and recycling of these elements. It is estimated that, from 2030, the end-of-life permanent magnets will be the main REE resource, implementing the circular economy pillars [5,10,14]. Nd-Fe-B permanent magnets have a life cycle of $2-30$ years, based on the specific application, shorter for electronic devices (e.g., hard disk drives) longer for wind turbines [5]. These permanent magnets could be easily dismantled, refurbished and reused, but, in this way, they show lower performance than the virgin material [9]. For this reason, several researches study the REE recovery from Nd-Fe-B permanent magnet using mainly pyro- or hydrometallurgical processes, but none is applied on industrial scale in Europe, yet $[5,10]$. The main pyrometallurgy techniques are chlorination [15-17] or sulfation roasting [18], liquid metal extraction with $\mathrm{Mg}$ [19], $\mathrm{Ag}$ [20] or $\mathrm{Cu}$ [21], molten extract with chloride [22], fluoride salts [23], $\mathrm{B}_{2} \mathrm{O}_{3}$ [24] or $\mathrm{CaO}-\mathrm{SiO}_{2}-\mathrm{Al}_{2} \mathrm{O}_{3}$ [25]. These approaches require high temperature (between 700 and $1500{ }^{\circ} \mathrm{C}$ ) and the main disadvantages are: the low product purity due to the presence of organic materials (e.g., adhesive or machining oil), different composition of the metal alloys, generated from the starting permanent magnet, and the loss of REE due to their affinity for oxygen [5,9]. On the other hand, hydrometallurgical approaches require lower temperature than pyrometallurgy, but they need the use of chemical agents that produce acid wastewater $[4,11,26,27]$. The main chemicals used for the REE recovery from permanent magnet are sulphuric [28-32] and hydrochloric acid [9,32-35].

In this work, three different processes are studied by the life cycle assessment approach to identify the best choice for the REE recovery and recycling of permanent magnets. Two hydrometallurgical treatments, with different resources of chloride ions (the first one using $\mathrm{HCl}$, the second one a solid-state chlorination), and a pyrometallurgical process are considered. This work aims to push and lead the stakeholders towards the implementation of sustainable processes for the permanent magnet exploitation, following the European Union guidelines for the circular economy.

\section{Materials and Methods}

\subsection{Process Description}

The present section describes the innovative processes considered for the environmental assessment. The description is combined with the energy and mass balance, referred to a functional unit of $1000 \mathrm{~kg}$ of Nd-Fe-B permanent magnets (Table 1). The selected processes (hydrometallurgical, pyrometallurgical and solid-state chlorination treatments) ensure a selective recovery of REE with a purity of the final product higher than $95 \%$.

\subsubsection{Hydrometallurgical Process}

Figure 1 shows the block diagram of the hydrometallurgical process [9]. After their preliminary demagnetisation at $310^{\circ} \mathrm{C}$ for $1 \mathrm{~h}$, the $\mathrm{Nd}$-Fe-B permanent magnets are grinded up to a particle size smaller the $150 \mu \mathrm{m}$. Before the chemical leaching with $0.5 \mathrm{M} \mathrm{HCl}$ solution, the particle substrates are roasted at $810^{\circ} \mathrm{C}$ for $6 \mathrm{~h}$ to convert iron to $\mathrm{Fe}_{2} \mathrm{O}_{3}$ that is less prone to the acid leaching, with minimum Fe dissolution. The REE ( Nd, Pr and Dy) leaching is carried out under these conditions: roasted magnet powder concentration of $10 \%(w / v)$, at $95{ }^{\circ} \mathrm{C}$ for $5 \mathrm{~h}$, with a resulting efficiency of $98 \%$ for REE with a low concentration of Fe ions $0.014 \mathrm{~g} / \mathrm{L}$. Therefore, the leaching solution is filtered and the $\mathrm{Fe}_{2} \mathrm{O}_{3}$ residue is recovered with a purity of $93 \%$. On the other hand, the resulting leaching solution is treated with oxalic acid for the REE precipitation. The recovered REE oxalates are roasted at $800{ }^{\circ} \mathrm{C}$ for $2 \mathrm{~h}$ to convert oxalates in oxides. The final recovery efficiency and purity are higher than $98 \%$. The resulting liquor is used for the further preparation of leaching solution. 
Table 1. Energy and mass balance of the three considered treatment for the end-of-life permanent magnet exploitation.

\begin{tabular}{|c|c|c|c|}
\hline Process & Step & Input & Output \\
\hline \multirow{6}{*}{ 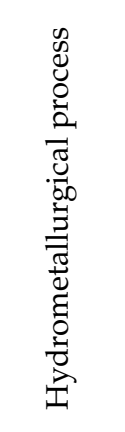 } & Demagnetisation & $58 \mathrm{kWh}$ & $1000 \mathrm{~kg}$ permanent magnet \\
\hline & Crushing and grinding & $10 \mathrm{kWh}$ & $1000 \mathrm{~kg}$ magnet powder $(<150 \mu \mathrm{m})$ \\
\hline & Oxidation & $369 \mathrm{kWh}$ & $1365 \mathrm{~kg}$ oxidized magnet powder \\
\hline & Leaching & $\begin{array}{l}13,600 \mathrm{~kg} \text { water } \\
250 \mathrm{~kg} \mathrm{HCl} \\
164 \mathrm{kWh}\end{array}$ & $\begin{array}{c}1080 \mathrm{~kg} \text { solid residue }\left(\mathrm{Fe}_{2} \mathrm{O}_{3} 93 \%\right) \\
13,100 \mathrm{~kg} \text { leaching solution }\end{array}$ \\
\hline & Precipitation & $\begin{array}{l}257 \mathrm{~kg} \text { oxalic acid } \\
41 \mathrm{kWh}\end{array}$ & $\begin{array}{c}662 \mathrm{~kg} \text { REE oxalates } \\
12,700 \mathrm{~kg} \text { solution residue }\end{array}$ \\
\hline & Roasting & $94 \mathrm{kWh}$ & $304 \mathrm{~kg}$ REE oxides \\
\hline \multirow{5}{*}{ 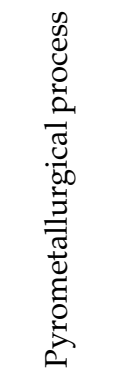 } & Demagnetisation & $58 \mathrm{kWh}$ & $1000 \mathrm{~kg}$ permanent magnet \\
\hline & Crushing and grinding & $10 \mathrm{kWh}$ & $1000 \mathrm{~kg}$ magnet powder $(<150 \mu \mathrm{m})$ \\
\hline & Oxidation & $434 \mathrm{kWh}$ & $1338 \mathrm{~kg}$ oxidized magnet powder \\
\hline & Reduction & $\begin{array}{l}6688 \mathrm{kWh} \\
0.15 \mathrm{~kg} \mathrm{Ar}\end{array}$ & $1070 \mathrm{~kg}$ oxidized magnet powder $+\mathrm{Fe}$ \\
\hline & Magnet separation & $1 \mathrm{kWh}$ & $\begin{array}{c}615 \mathrm{~kg} \mathrm{Fe} \\
455 \mathrm{~kg} \text { REE oxides }\end{array}$ \\
\hline \multirow{8}{*}{ 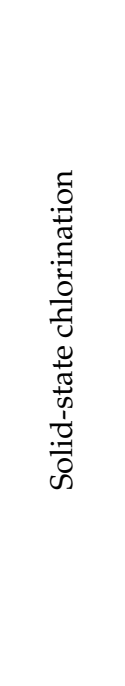 } & Demagnetisation & $66 \mathrm{kWh}$ & $1000 \mathrm{~kg}$ permanent magnet \\
\hline & Crushing and grinding & $100 \mathrm{kWh}$ & $1000 \mathrm{~kg}$ magnet powder $(<100 \mu \mathrm{m})$ \\
\hline & Mixing & $1500 \mathrm{~kg} \mathrm{NH}{ }_{4} \mathrm{Cl}$ & $2500 \mathrm{~kg}$ magnet powder $+\mathrm{NH}_{4} \mathrm{Cl}$ \\
\hline & Solid-state chlorination & $\begin{array}{l}1740 \mathrm{kWh} \\
116 \mathrm{~kg} \mathrm{~N}_{2}\end{array}$ & $\begin{array}{c}480 \mathrm{~kg} \mathrm{NH} 3 \\
1990 \mathrm{~kg} \text { magnet powder }+\mathrm{NH}_{4} \mathrm{Cl}\end{array}$ \\
\hline & Ammonia production & $1910 \mathrm{~kg}$ water & $1910 \mathrm{~kg}$ ammonia solution \\
\hline & Buffer leaching & $\begin{array}{c}21,000 \mathrm{~kg} \text { water } \\
630 \mathrm{~kg} \mathrm{C}{ }_{2} \mathrm{H}_{4} \mathrm{O}_{2} \\
30 \mathrm{~kg} \mathrm{NaCH} \mathrm{COO}_{3} \cdot 2 \mathrm{H}_{2} \mathrm{O}\end{array}$ & $\begin{array}{c}316 \mathrm{~kg} \text { magnet residue need a second } \\
\text { solid-state chlorination } \\
23,040 \mathrm{~kg} \text { leaching solution }\end{array}$ \\
\hline & $\begin{array}{c}\text { REE solvent } \\
\text { extraction/precipitation }\end{array}$ & $\begin{array}{l}2259 \mathrm{~kg} \text { DEPHA } \\
1581 \mathrm{~kg} \text { n-heptane } \\
2032 \mathrm{~kg} \mathrm{H} \mathrm{PO}_{4} \\
5646 \mathrm{~kg} \text { water }\end{array}$ & $\begin{array}{c}463 \mathrm{~kg} \text { REE phosphate } \\
23,150 \mathrm{~kg} \text { solution residue }\end{array}$ \\
\hline & Fe recovery & $4630 \mathrm{~kg}$ oxalic acid & $\begin{array}{c}1535 \mathrm{~kg} \text { Fe oxalate } \\
20,000 \mathrm{~kg} \text { solution residue }\end{array}$ \\
\hline
\end{tabular}

\subsubsection{Pyrometallurgical Process}

The pyrometallurgical process includes a preliminary demagnetisation at $310{ }^{\circ} \mathrm{C}$ for $1 \mathrm{~h}$ (comparable with that described by Kumari et al. (2018)) and the permanent magnets grinding with a final particle size lower than $150 \mu \mathrm{m}$ (Figure 2) [36]. The resulting Nd-Fe-B magnet powder is oxidised at $1000{ }^{\circ} \mathrm{C}$ for $2 \mathrm{~h}$ to convert metals to the mixture of the oxides $\left(\mathrm{Nd}_{2} \mathrm{O}_{3}, \mathrm{Pr}_{2} \mathrm{O}_{3}, \mathrm{La}_{2} \mathrm{O}_{3}, \mathrm{Fe}_{2} \mathrm{O}_{3}, \mathrm{Al}_{2} \mathrm{O}_{3}\right.$ and $\left.\mathrm{B}_{2} \mathrm{O}_{3}\right)$. Thereafter, the metal oxides are heated at $1400-1550{ }^{\circ} \mathrm{C}$ for $7 \mathrm{~h}$ to reduce $\mathrm{Fe}_{2} \mathrm{O}_{3}$ to iron by carbon, under Ar atmosphere $(200 \mathrm{~mL} / \mathrm{min})$. The resulting iron is removed by magnetic separation. The final REE oxide purity is higher than $95 \%$, and the main impurities are $\mathrm{Al}_{2} \mathrm{O}_{3}$ and $\mathrm{B}_{2} \mathrm{O}_{3}$. 


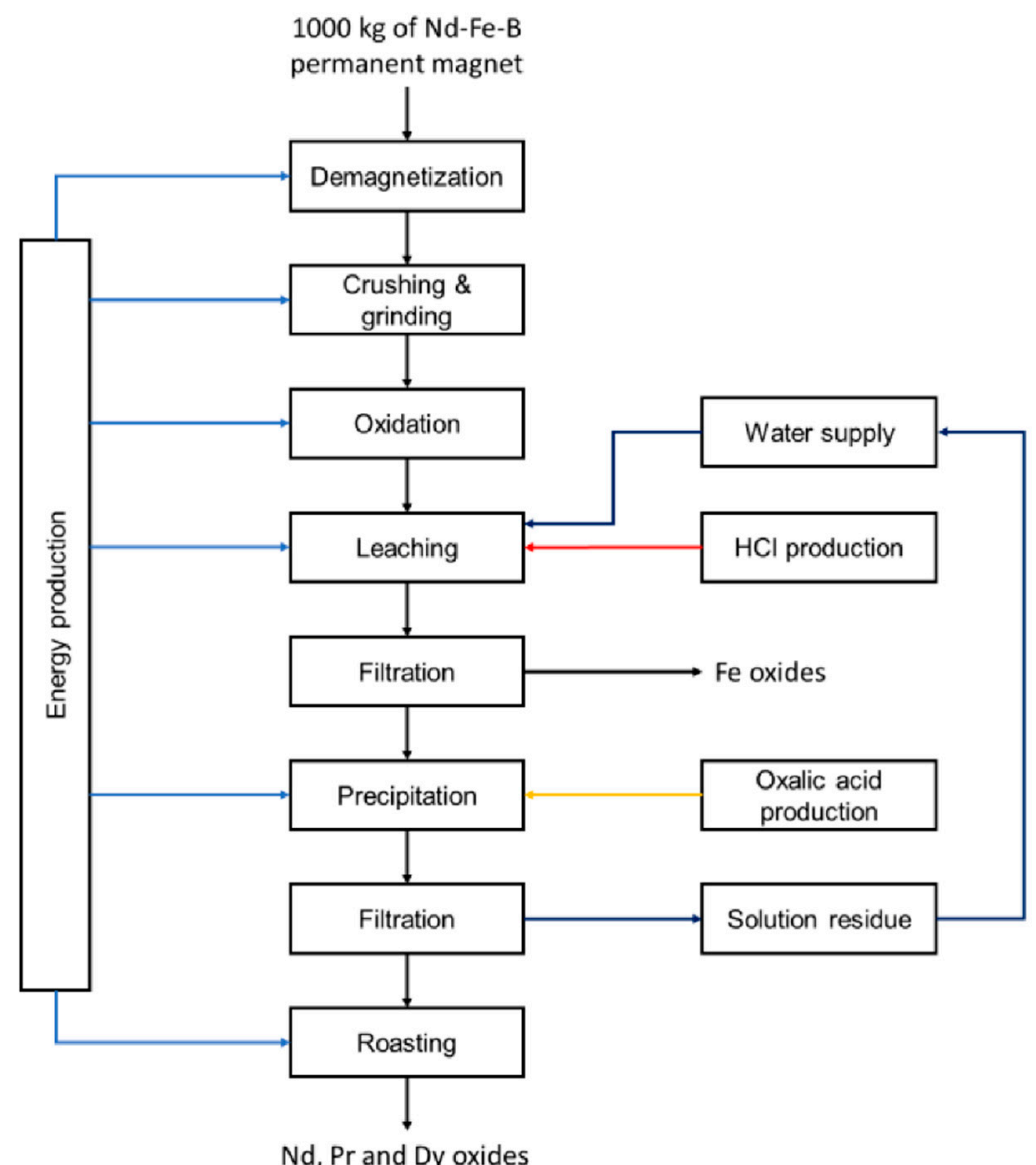

Figure 1. Block diagram of the hydrometallurgical process [9].

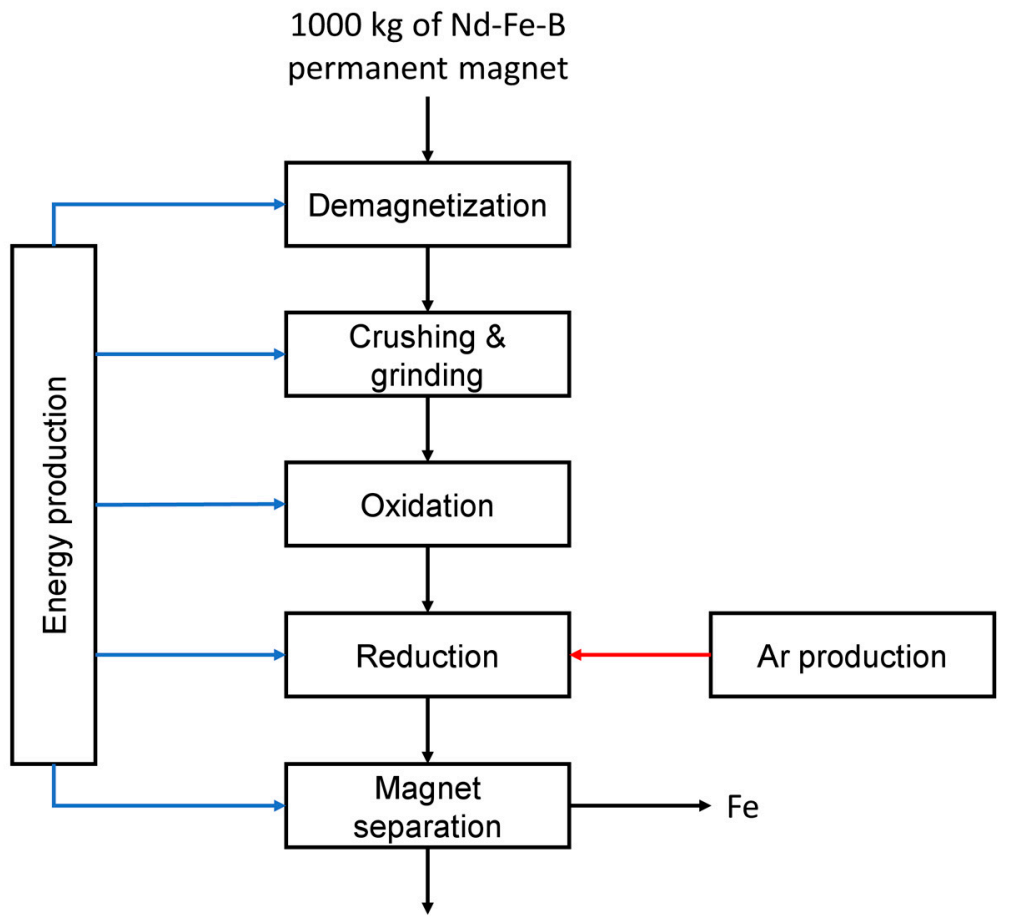

$\mathrm{Nd}$, La and Dy oxides

Figure 2. Block diagram of pyrometallurgical process (adapted from Bian et al. (2015) [36]). 


\subsubsection{Solid-State Chlorination Process}

The third process is the solid-state chlorination [10]. This process has some advantages compared to the common hydrometallurgical processes: the low reagent request, the low economic cost and the avoided production of acid wastewater. As showed in Figure 3, the $\mathrm{Nd}$-Fe-B permanent magnets are firstly demagnetised at $350{ }^{\circ} \mathrm{C}$ for $2 \mathrm{~h}$ and then ground to particle size lower than $100 \mu \mathrm{m}$. After these pre-treatments, the magnet powder is mixed with $\mathrm{NH}_{4} \mathrm{Cl}\left(1: 3 w / w\right.$, magnet: $\left.\mathrm{NH}_{4} \mathrm{Cl}\right)$. The solid-state chlorination is carried out at $285^{\circ} \mathrm{C}$ for $2.5 \mathrm{~h}$. At this temperature $\mathrm{NH}_{4} \mathrm{Cl}$ is decomposed following the Equation (1), and the gaseous $\mathrm{HCl}$ reacts with metals to form metal chloride (Equations (2) and (3)):

$$
\begin{gathered}
\mathrm{NH}_{4} \mathrm{Cl}(\mathrm{s}) \rightarrow \mathrm{NH}_{3}(\mathrm{~g})+\mathrm{HCl}(\mathrm{g}) \\
\mathrm{Fe}(\mathrm{s})+2 \mathrm{HCl}(\mathrm{g}) \rightarrow \mathrm{FeCl}_{2}(\mathrm{~s})+\mathrm{H}_{2}(\mathrm{~g}) \\
\mathrm{REE}(\mathrm{s})+3 \mathrm{HCl}(\mathrm{g}) \rightarrow \mathrm{REECl}_{3}(\mathrm{~s})+3 / 2 \mathrm{H}_{2}(\mathrm{~g})
\end{gathered}
$$

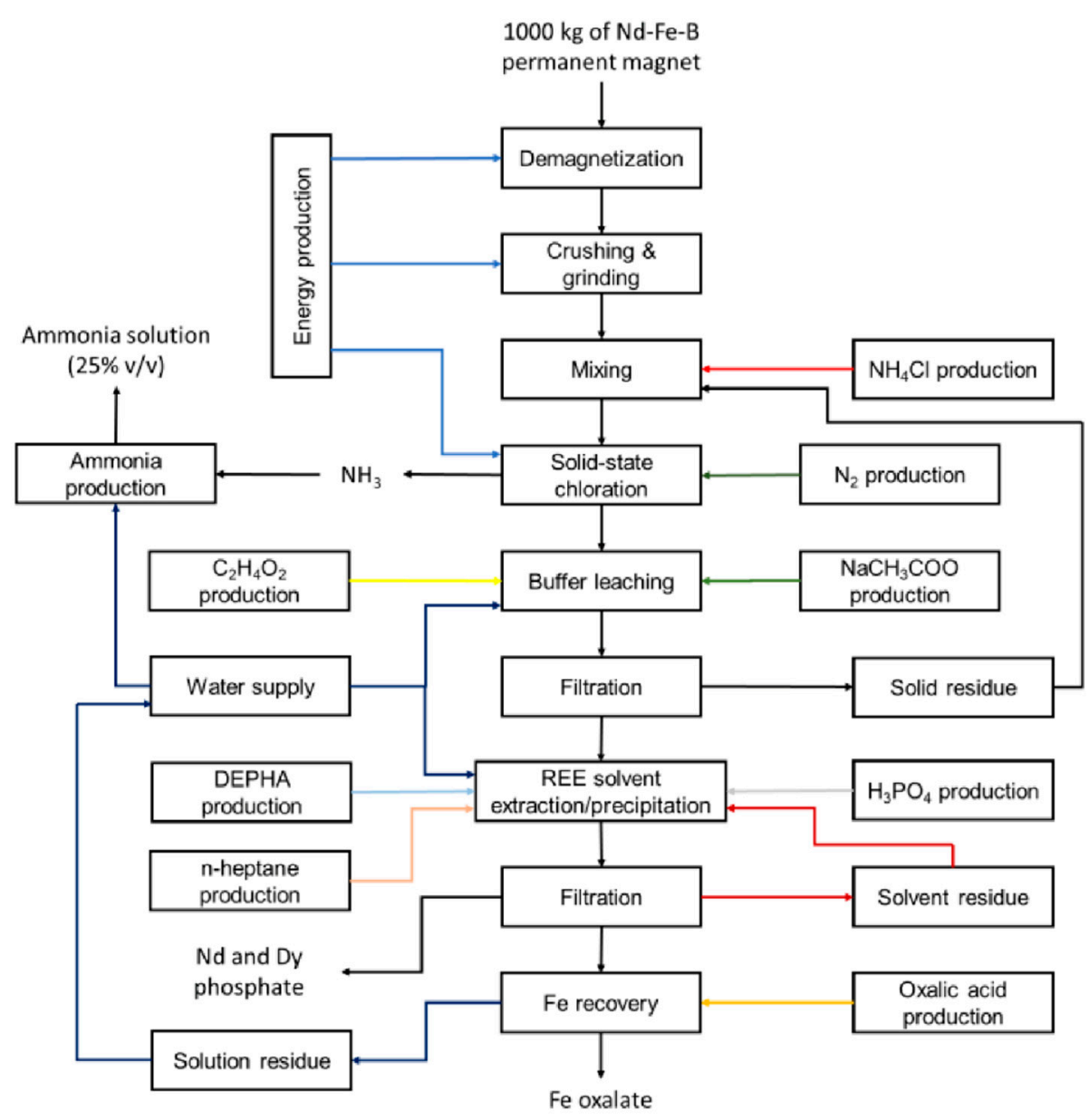

Figure 3. Block diagram of solid-state chlorination process $[10,11]$.

The unreacted $\mathrm{NH}_{4} \mathrm{Cl}$ is recovered and reused for further solid-state chlorination. Thereafter, the permanent magnets are treated with a buffer solution $(21.02 \mathrm{~g}$ of buffer solution/g of permanent magnet). The buffer solution is composed of $0.5 \mathrm{M}$ acetic acid and $0.01 \mathrm{M} \mathrm{NaCH}_{3} \mathrm{COO} \cdot 3 \mathrm{H}_{2} \mathrm{O}$ solution at $\mathrm{pH}$ 3. The leaching is carried out at room temperature for $2.5 \mathrm{~h}$. This process allows to achieve a leaching efficiency around $93 \%$ and $84 \%$ for Fe and REE, respectively. The remaining $16 \%$ of the REE in the solid residue can be recovered with a second solid-state chlorination. The main disadvantage is the co-leaching of iron, solved by a solvent extraction, following the method described by Amato et al. (2019), considered for the present sustainability analysis. More in detail, the recovery step 
is carried out with an organic solvent bis-(2-ethylhexyl)phosphoric acid (DEHPA), diluted in n-heptane, at a concentration of $50 \% v / v$. The solvent solution is treated with a $\mathrm{H}_{3} \mathrm{PO}_{4}$ solution for the selective REE precipitation with a recovery efficiency of $98 \%$. The $95 \%$ of both the solvent and the aqueous solution can be recirculated. Thereafter, iron is recovered from buffer solution by precipitation with oxalic acid [11,37].

\subsection{Life Cycle Assessment}

The life cycle assessment (LCA) takes into account the energy and mass balance of the three reported processes for the Nd-Fe-B permanent magnet exploitation (from gate to gate) (Table 1), and it is carried out in agreement with the LCA ISO standard 14040 and 14044:2006 [38,39]. The selected functional unit for the assessment is $1000 \mathrm{~kg}$ of end-of-life permanent magnet. The software used for the data collection is thinkstep Gabi 9.5. The method selected for the analysis is EF 3.0, including all the environmental categories, recommended models at midpoint, together with their indicators, units and sources [40,41]. The process considered for the present assessment are developed at laboratory scale; some sensible assumptions are made to hypothesise the further scale-up [42-44]. The considered assumptions are reported below:

- Industrial machineries are considered to calculate the energy demand for the mechanical/physical treatments (e.g., demagnetisation, grinding, heating) [42];

- The filtration and mixing energy demand are considered negligible due to the lower value than the other processes $(<0.002 \mathrm{kWh} / \mathrm{kg}$ end-of-life permanent magnet) $[45,46]$;

- The by-products $\left(\mathrm{Fe}_{2} \mathrm{O}_{3}\right.$ or $\mathrm{Fe}$ oxalate) are considered as environmental credits since they could be used in different processes, e.g., for environmental remediation strategies [47] or as anode in the lithium-ions batteries [48], respectively;

- The 95\% recirculation of the organic solvent for REE extraction is considered [11];

- The $\mathrm{NH}_{3}$ gas, generated during the solid-state chlorination, is recovered and used to produce an ammonia solution with a final concentration of $25 \%(v / v)$ and a purity higher than $99 \%$ [10];

- The solution resulting from the recovery step is used to prepare further leaching solutions [9,11];

- Considering the absence of $\mathrm{Nd}, \mathrm{Pr}$ and Dy oxides in the reference database, their environmental burdens have been estimated by the allocation of $\mathrm{La}_{2} \mathrm{O}_{3}$ impact, on the market price basis [49];

- The oxalic acid production process, considered for the analysis is that described by Santoro et al. (1999), using milk whey as carbon source [50].

\section{Results}

Figure 4 reports the results of classification and characterisation phases of LCA. Overall, it is evident that the high recovery efficiency of the three options represents a very important benefit from the environmental point of view, with an advantage of the solidstate chlorination. Indeed, the environmental credit of REE balances and overcomes the process burdens, in most considered categories. The main advantage is connected to $\mathrm{Nd}$ oxide, mainly for the highest recovered quantities, compared to the other REE. A contribution between $14 \%$ and $19 \%$ is assigned to Pr oxide in both hydrometallurgical and pyrometallurgical options. On the other hand, in solid-state chlorination process, the environmental credit is equally distributed between $\mathrm{Nd}$ and Dy oxides. The choice of environmental impact allocation on the economic price explains relevant effect of Dy oxide, even if its recovered quantity is around six times lower than $\mathrm{Nd}$ oxide. Indeed, the price of these REE, at January 2020, reports a value of 251.11 USD $/ \mathrm{kg}$ for Dy oxide vs. 41.76 USD/kg for Nd oxide [49]. 


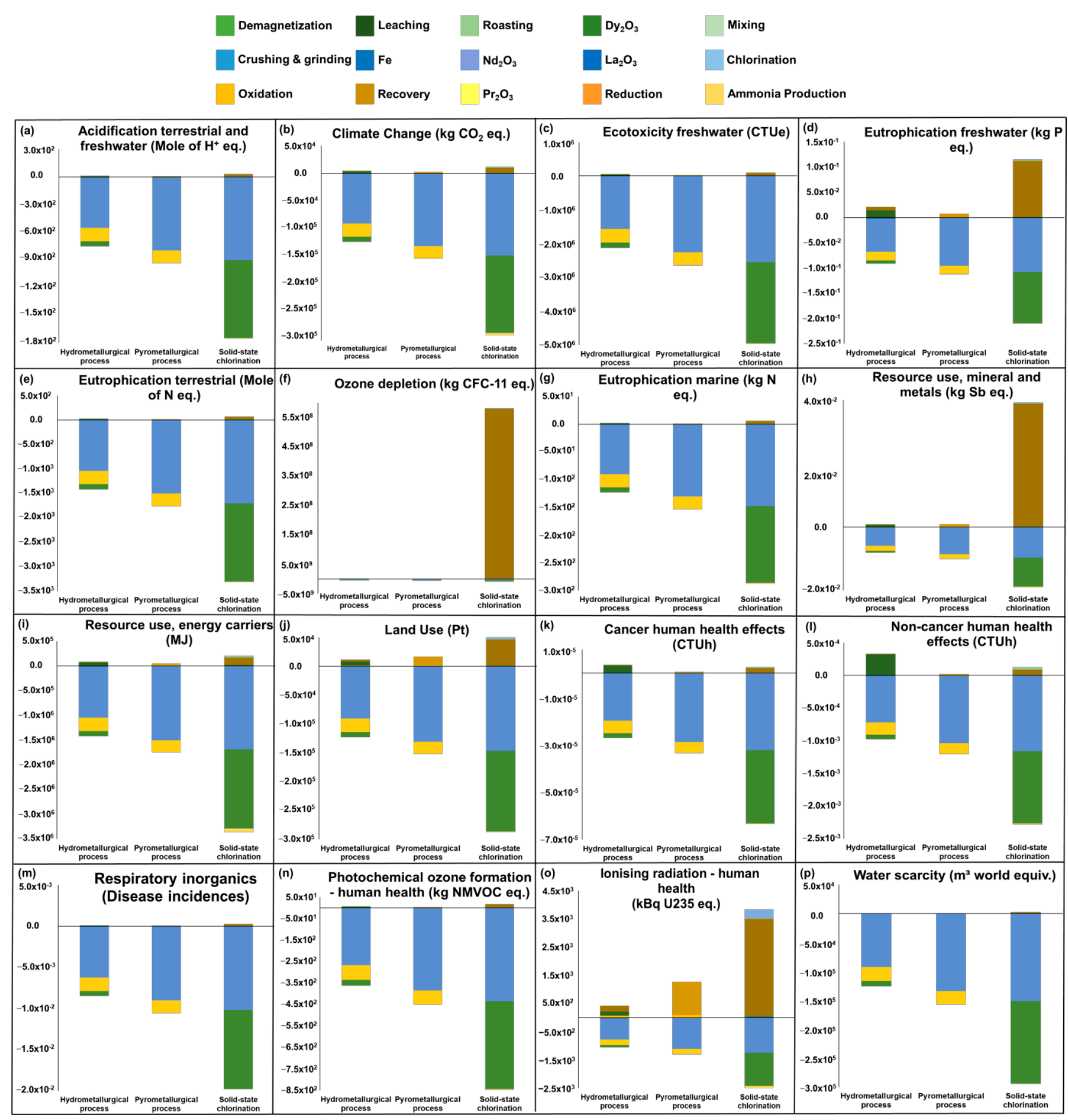

Figure 4. Results of classification and characterisation steps of LCA, the figures from a-p represent the considered impact categories (functional unit: $1000 \mathrm{~kg}$ of Nd-Fe-B permanent magnets).

A separate discussion is reserved to the categories of resource use, mineral and metals and ozone depletion (Figure 4f,h), which identify the solid-state chlorination as the worst option. The burden of recovery step on the ozone depletion is due to the use of n-heptane, in the third option. On the other hand, the phosphoric acid affects the category of resource use, mineral and metals, due to the mining of phosphate rock used for its production [51].

The classification and characterisation steps supply essential information to define the most sustainable process for the permanent magnet exploitation. Nevertheless, Figure 5 shows the most complete overview thanks to the estimation of the environmental perfor- 
mance index (EPI) able to include all the impact categories. This value is expressed as person equivalent (p.e.), which represents the number of average citizens that generates the same impact in one year [52]. As reported in Figure 5, the hydrometallurgical process causes the lowest environmental burden. Nevertheless, the greatest credit achieved by solid state chlorination makes this option the most environmentally sustainable choice. Overall, the negative value of EPI, confirms the benefit of the permanent magnet recycling, compared to the primary production of REE.

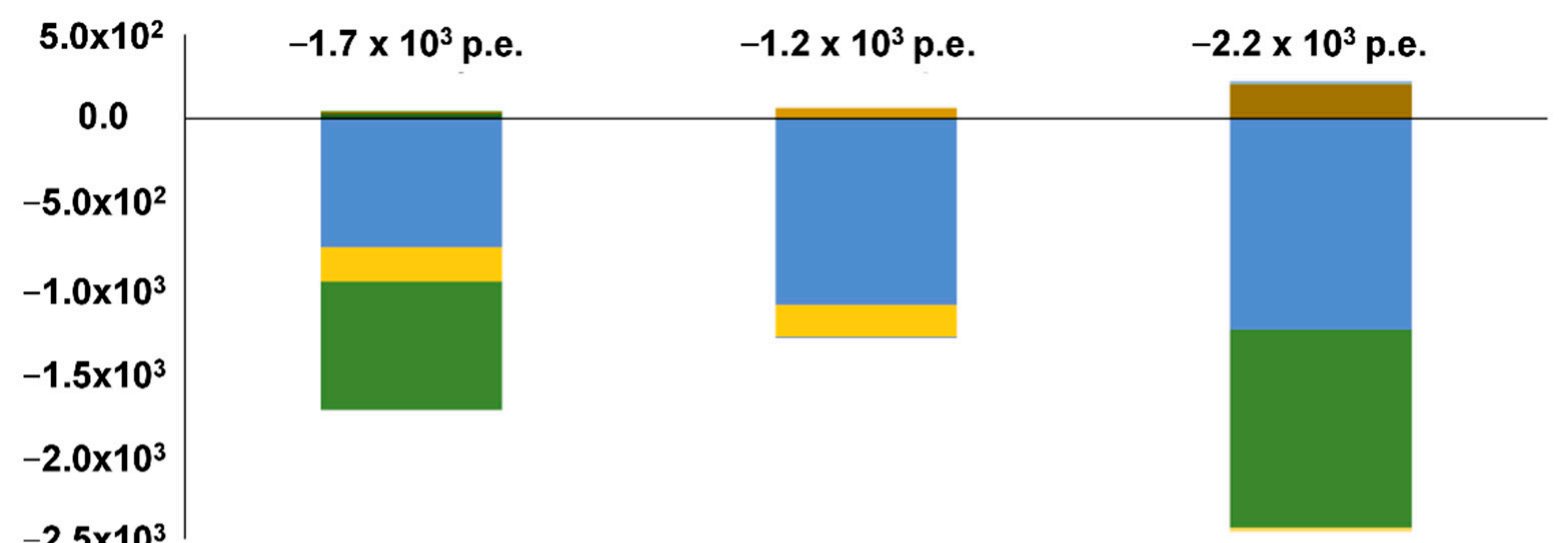

$-2.5 \times 10^{3}$

Hydrometallurgical process

\section{Pyrometallurgical} process

- Demagnetization
- Leaching
$=$ Roasting
$\square \mathrm{Dy}_{2} \mathrm{O}_{3}$
$=$ Mixing

Figure 5. Normalisation and weighing results of the three treatments: effect of the different step expressed as p.e. (functional unit: $1000 \mathrm{~kg}$ of Nd-Fe-B permanent magnets).

To better compare the impacts of the three analysed processes, Figure 6 shows the effects on the different impact categories, dividing the most affected by the process (Figure 6a) and the most favored by REE recovered (Figure $6 \mathrm{~b}$ ). It is evident that the ionising radiationhuman health represents the main issue. This effect is explained by the electricity demand necessary for the synthesis of oxalic acid used in the recovery step in both hydrometallurgical and solid-state chlorination processes. Furthermore, the high energy request of pyrometallurgical technique (mainly due to the reduction phase) explains the contribution greater than $70 \%$ of this impact category on the whole impact. The effect of energy supply on the ionizing radiation-human health category is due to the European electricity grid mix considered for the analysis (supplied by Gabi database), particularly to the radionuclides (potentially toxic for humans) resulting from both the nuclear energy production, and the mineral oil and gas extraction, used as energy carriers [46,53]. As reported in Figure 6b, the benefit of REE recovery is mainly highlighted in the categories of climate change and resource use, and energy carriers. The highest credit resulting from the solid-state chlorination balances its greatest burden making this option the most sustainable and the pyrometallurgical process the worst choice. 
(a)

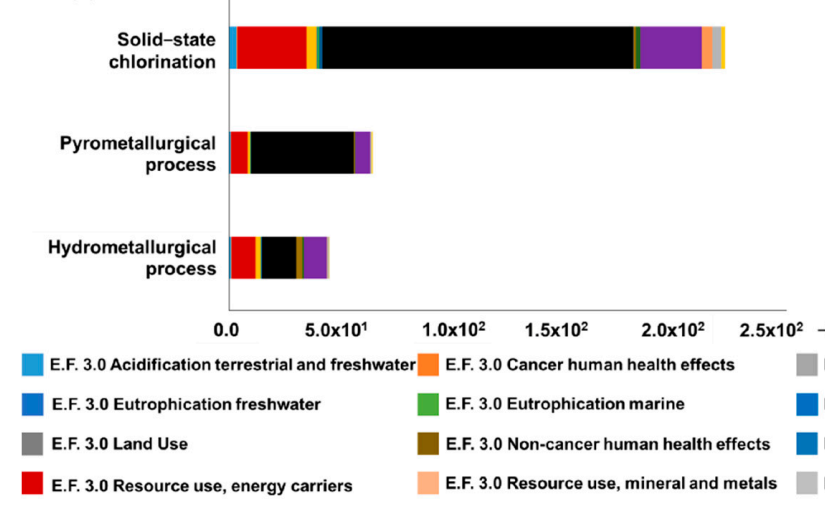

(b)

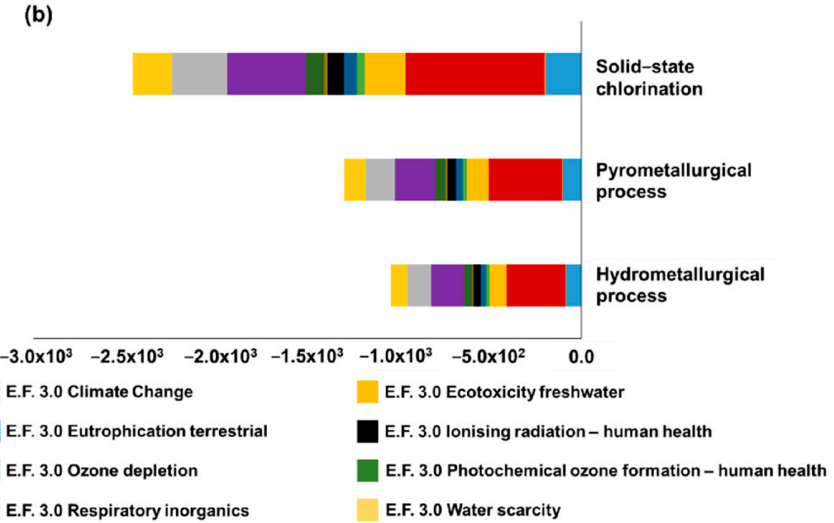

Figure 6. Normalisation and weighing results: (a) the main affected impact categories by processes and (b) the main saved impact categories by REE recovery, expressed as p.e. (functional unit: $1000 \mathrm{~kg}$ of Nd-Fe-B permanent magnets).

\section{Sensitivity Analysis}

The choice of the allocation method based on the economic price of REE oxides could cause an uncertainty on the whole result, due to the fluctuation of the REE prices. For this reason, the assessment of EPI has been repeated estimating Nd, Pr and Dy credits by the allocation of $\mathrm{La}_{2} \mathrm{O}_{3}$ impact, on the market price in 2009, reported in Table 2.

Table 2. Market price of REE oxides, comparison between 2009 [54] and 2020 [49].

\begin{tabular}{ccccc}
\hline \multirow{2}{*}{ Reference Year } & La Oxide & Pr Oxide & Nd Oxide & Dy Oxide \\
\cline { 2 - 5 } & \multicolumn{3}{c}{ USD/kg } \\
\hline 2009 & 6.25 & 14.0 & 14.0 & 100 \\
2020 & 1.69 & 48.4 & 41.8 & 251 \\
\hline
\end{tabular}

As reported in Figure 7, the exploitation of permanent magnets as secondary resource of REE oxides results an environmentally sustainable choice, irrespective of the specific metal prices. Indeed, the assessed EPI show negative value despite the lower prices in 2009 than 2020. Nevertheless, the effect of market fluctuation is evident and significantly affects the balance between burden and benefit. The sensitivity analysis shows that the most relevant effect is the variation of Dy price, which cancels the advantage of the solid-state chlorination, in favor of the hydrometallurgical option. Therefore, the simple design and the lowest burden resulting from this process make this option the most environmentally sustainable, despite the lowest quantity of recovered REE, irrespective of the market price.

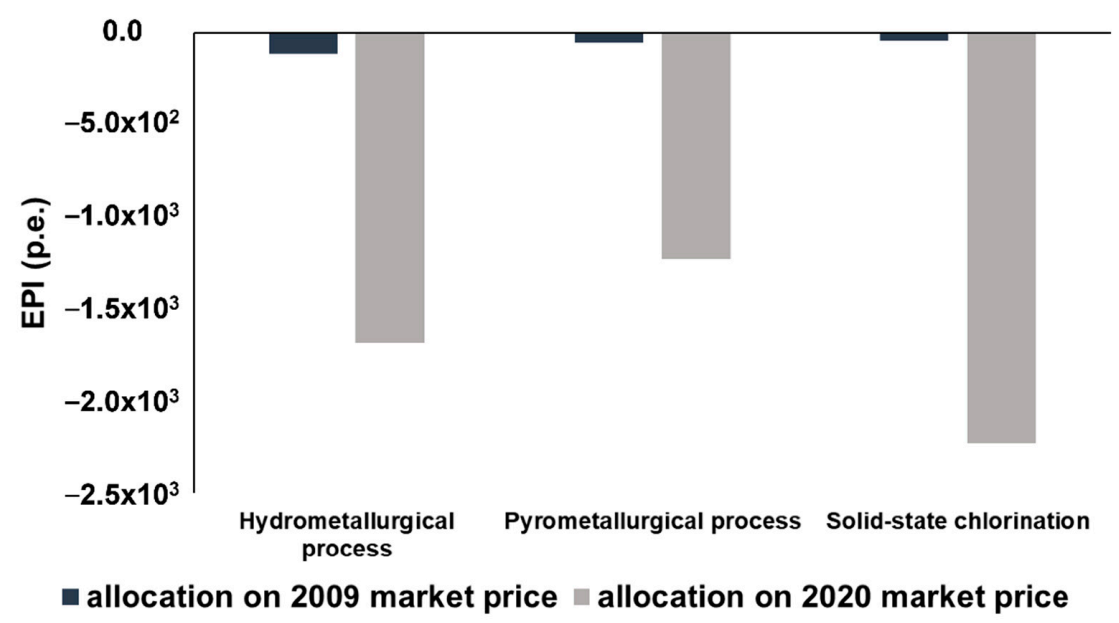

Figure 7. Comparison between the EPI resulting from the allocation on 2009 and 2020 REE oxide prices. 


\section{Conclusions}

The identification of the most sustainable choice for the exploitation of permanent magnets represents a hot topic and it is set to become ever more relevant considering the increasing applications of this technology, and the growing REE demand. The environmental sustainability analysis proved the benefit of recycling treatments, compared to the primary production of metals, irrespective of the chosen approach. Nevertheless, the LCA showed that the economic aspects affect the final choice. More in detail, high economic value of the REE pushes towards the highest recovery processes (but greater environmental burden), that is, the solid-state chlorination. On the other hand, the simple design of the hydrometallurgical treatment ensures high environmentally sustainability levels, irrespective of the market fluctuation. The present paper represents an excellent example of implementation of LCA as support tool for the definition of circular economy strategies.

Author Contributions: Conceptualisation, F.B.; methodology, A.A.; software, A.A.; validation, A.A. and A.B.; formal analysis, A.A., A.B. and F.B.; investigation, F.B.; resources, A.A.; data curation, A.A. and A.B.; writing—original draft preparation, A.A. and A.B.; writing—review and editing, A.A.; visualisation, A.B.; supervision, A.A.; project administration, F.B.; funding acquisition, A.A. All authors have read and agreed to the published version of the manuscript.

Funding: This research received no external funding.

Institutional Review Board Statement: Not applicable.

Informed Consent Statement: Not applicable.

Acknowledgments: The authors are grateful to Riccardo Maiolatesi for his precious collaboration in data collection.

Conflicts of Interest: The authors declare no conflict of interest.

\section{References}

1. European Commission. The European Green Deal. Eur. Commun. 2019, 53, 24. [CrossRef]

2. Oberle, B.; Bringezu, S.; Hatfileld-Dodds, S.; Hellweg, S.; Schandl, H.; Clement, J. Global Resources Outlook 2019; International Resource Panel, United Nations Environment Programme: Paris, France, 2020. [CrossRef]

3. Nakamura, H. The current and future status of rare earth permanent magnets. Scr. Mater. 2018, 154, 273-276. [CrossRef]

4. Yin, X.; Yue, M.; Lu, Q.; Liu, M.; Wang, F.; Qiu, Y.; Liu, W.; Zuo, T.; Zha, S.; Li, X.; et al. An efficient process for recycling Nd-Fe-B sludge as high-performance sintered magnets. Engineering 2020, 6, 165-172. [CrossRef]

5. Yang, Y.; Walton, A.; Sheridan, R.; Güth, K.; Gauß, R.; Gutfleisch, O.; Buchert, M.; Steenari, B.M.; Van Gerven, T.; Jones, P.T.; et al. REE recovery from end-of-life NdFeB permanent magnet scrap: A Critical Review. J. Sustain. Metall. 2017, 3, 122-149. [CrossRef]

6. München, D.D.; Veit, H.M. Neodymium as the main feature of permanent magnets from hard disk drives (HDDs). Waste Manag. 2017, 61, 372-376. [CrossRef] [PubMed]

7. Rademaker, J.H.; Kleijn, R.; Yang, Y. Recycling as a strategy against rare earth element criticality: A systemic evaluation of the potential yield of NdFeB magnet recycling. Environ. Sci. Technol. 2013, 47, 10129-10136. [CrossRef] [PubMed]

8. Pan, S. Rare Earth Permanent Magnet Alloys' High Temperature Phase Transformation: In Situ and Dynamic Observation and Its Application in Material Design; Springer: Berlin/Heidelberg, Germany, 2013.

9. Kumari, A.; Sinha, M.K.; Pramanik, S.; Sahu, S.K. Recovery of rare earths from spent NdFeB magnets of wind turbine: Leaching and kinetic aspects. Waste Manag. 2018, 75, 486-498. [CrossRef]

10. Lorenz, T.; Bertau, M. Recycling of rare earth elements from FeNdB-Magnets via solid-state chlorination. J. Clean. Prod. 2019, 215, 131-143. [CrossRef]

11. Amato, A.; Becci, A.; Birloaga, I.; De Michelis, I.; Ferella, F.; Innocenzi, V.; Ippolito, N.M.; Jimenez, C.P.; Vegliò, F.; Beolchini, F. Sustainability analysis of innovative technologies for the rare earth elements recovery. Renew. Sustain. Energy Rev. 2019, 106, 41-53. [CrossRef]

12. Elwert, T.; Goldmann, D.; Roemer, F.; Schwarz, S. Recycling of NdFeB magnets from electric drive motors of (Hybrid) electric vehicles. J. Sustain. Metall. 2017, 3, 108-121. [CrossRef]

13. Hurst, C. China's Rare Earth Elements Industry: What Can the West Learn? Institute for the Analysis of Global Security: Washington, DC, USA, 2010.

14. Sullivan, K.; Thomas, S.; Rosano, M. Using industrial ecology and strategic management concepts to pursue the sustainable development goals. J. Clean. Prod. 2018, 174, 237-246. [CrossRef]

15. Okabe, T.H.; Shirayama, S. Method and Apparatus for Recovery of Rare Earth Element. U.S. Patent 8323592 B2, 4 December 2012. 
16. Gnanam, S.; Rajendran, V. Facile sol-gel preparation of Cd-doped cerium oxide $\left(\mathrm{CeO}_{2}\right)$ nanoparticles and their photocatalytic activities. J. Alloys Compd. 2018, 735, 1854-1862. [CrossRef]

17. Murase, K.; Machida, K.; Adachi, G. Recovery of rare metals from scrap of rare earth intermetallic material by chemical vapour transport. J. Alloys Compd. 1995, 217, 218-225. [CrossRef]

18. Önal, M.A.R.; Borra, C.R.; Guo, M.; Blanpain, B.; Van Gerven, T. Recycling of NdFeB magnets using sulfation, selective roasting, and water leaching. J. Sustain. Metall. 2015, 1, 199-215. [CrossRef]

19. Ellis, T.W.; Schmidt, F.A. Recycling of Rare Earth Metals from Rare Eart-Transition Metal Alloy Scrap by Liquid Metal Extraction. U.S. Patent 5,437,709, 1 August 1995.

20. Takeda, O.; Okabe, T.H.; Umetsu, Y. Phase equilibrium of the system Ag-Fe-Nd, and Nd extraction from magnet scraps using molten silver. J. Alloys Compd. 2004, 379, 305-313. [CrossRef]

21. Moore, M.; Gebert, A.; Stoica, M.; Uhlemann, M.; Löser, W. A route for recycling Nd from Nd-Fe-B magnets using Cu melts. J. Alloys Compd. 2015, 647, 997-1006. [CrossRef]

22. Hua, Z.; Wang, J.; Wang, L.; Zhao, Z.; Li, X.; Xiao, Y.; Yang, Y. Selective extraction of rare earth elements from NdFeB scrap by molten chlorides. ACS Sustain. Chem. Eng. 2014, 2, 2536-2543. [CrossRef]

23. Tanaka, M.; Oki, T.; Koyama, K.; Narita, H.; Oishi, T. Recycling of rare earths from scrap. In Handbook on the Physics and Chemistry of Rare Earths, 1st ed.; Elsevier BV: Amsterdam, The Netherlands, 2013; Volume 43. [CrossRef]

24. Saito, T.; Sato, H.; Ozawa, S.; Yu, J.; Motegi, T. The extraction of Nd from waste Nd-Fe-B alloys by the glass slag method. J. Alloys Compd. 2003, 353, 189-193. [CrossRef]

25. Yang, Y.; Abrahami, S.; Xiao, Y. Recovery of rare earth elements from EOL permanent magnets with slag extraction. In Proceedings of the 3rd International Slag Valorisation Symposium, Leuven, Belgium, 19-20 March 2013; pp. $249-252$.

26. Belova, V.V. Development of solvent extraction methods for recovering rare earth metals. Theor. Found. Chem. Eng. 2017, 51, 599-609. [CrossRef]

27. Jha, M.K.; Kumari, A.; Panda, R.; Rajesh Kumar, J.; Yoo, K.; Lee, J.Y. Review on hydrometallurgical recovery of rare earth metals. Hydrometallurgy 2016, 165, 2-26. [CrossRef]

28. Abrahami, S.T.; Xiao, Y.; Yang, Y. Rare-earth elements recovery from post-consumer hard-disc drives. Trans. Inst. Min. Metall. Sect. C Miner. Process. Extr. Metall. 2015, 124, 106-115. [CrossRef]

29. Lyman, J.W.; Palmer, G.R. Recycling of rare earths and iron from NdFeB magnet scrap. High Temp. Mater. Process. 1993, 11, 175-188. [CrossRef]

30. Ellis, T.W.; Schmidt, F.A.; Jones, L.L. Methods and opportunities in the recycling of rare earth based materials. In Proceedings of the Metallurgical Society (TMS) conference on high performance composites, Rosemont, IL, USA, 10-15 October 1994. No. IS-M-796, CONF-9410184-5.

31. Lee, J.; Jha, A.K.; Kumari, A.; Kumar, J.R.; Jha, M.K.; Kumar, V. Neodymium recovery by precipitation from synthetic leach liquor of concentrated rare earth mineral. J. Metall. Mater. Sci. 2011, 53, 349-354.

32. Lee, C.H.; Chen, Y.J.; Liao, C.H.; Popuri, S.R.; Tsai, S.L.; Hung, C.E. Selective leaching process for neodymium recovery from scrap Nd-Fe-B magnet. Metall. Mater. Trans. A Phys. Metall. Mater. Sci. 2013, 44, 5825-5833. [CrossRef]

33. Bandara, H.M.D.; Field, K.D.; Emmert, M.H. Rare earth recovery from end-of-life motors employing green chemistry design principles. Green Chem. 2016, 18, 753-759. [CrossRef]

34. Itakura, T.; Sasai, R.; Itoh, H. Resource recovery from Nd-Fe-B sintered magnet by hydrothermal treatment. J. Alloys Compd. 2006, 408-412, 1382-1385. [CrossRef]

35. Tanaka, Y.; Zhang, Q.; Saito, F. Sono chemical recovery of metals from recording media. J. Chem. Eng. Japan. 2002, 35, 173-177. [CrossRef]

36. Bian, Y.Y.; Guo, S.Q.; Xu, Y.L.; Tang, K.; Lu, X.G.; Ding, W.Z. Recovery of rare earth elements from permanent magnet scraps by pyrometallurgical process. Rare Met. 2015, 1-6. [CrossRef]

37. Birloaga, I.P.; Vegliò, F. Hydrometallurgical Process for the Treatment of Permanent Magnets. IT102018 2018:000005178. WO2019215583A1, 2019.

38. UNI EN ISO 14040:2006. Environmental Management-Life Cycle Assessment-Principles and Framework. 2006. Available online: https:/ / www.iso.org/standard/37456.html (accessed on 28 April 2021).

39. ISO 14044:2006. Environmental Management_Life Cycle Assessment-Requirements and Guidelines. 2006. Available online: https:/ / www.iso.org/standard/38498.html (accessed on 28 April 2021).

40. European Commission. Characterisation Factors of the ILCD Recommended Life Cycle Impact Assessment Methods; EUR 25167 EN; European Commission: Brussels, Belgium, 2012. [CrossRef]

41. Zampori, L.; Pant, R. Suggestions for Updating the Product Environmental Footprint (PEF) Method; Publication Office of the European Union: Luxembourg, 2019. [CrossRef]

42. Van der Hulst, M.K.; Huijbregts, M.A.J.; van Loon, N.; Theelen, M.; Kootstra, L.; Bergesen, J.D.; Hauck, M. A systematic approach to assess the environmental impact of emerging technologies: A case study for the GHG footprint of CIGS solar photovoltaic laminate. J. Ind. Ecol. 2020, 24, 1234-1249. [CrossRef]

43. Caduff, M.; Huijbregts, M.A.J.; Koehler, A.; Althaus, H.J.; Hellweg, S. Scaling relationships in Life Cycle Assessment: The case of heat production from biomass and heat pumps. J. Ind. Ecol. 2014, 18, 393-406. [CrossRef] 
44. Gavankar, S.; Suh, S.; Keller, A.A. The role of scale and technology maturity in Life Cycle Assessment of emerging technologies: A case study on carbon nanotubes. J. Ind. Ecol. 2015, 19, 51-60. [CrossRef]

45. Safaat, J.; Haque, N.; Rosano, M.; Biswas, W. Application of a life cycle assessment to compare environmental performance in coal mine tailings management. J. Environ. Manag. 2017, 199, 181-191. [CrossRef]

46. Amato, A.; Mastrovito, M.; Becci, A.; Beolchini, F. Environmental sustainability analysis of case studies of agriculture residue exploitation. Sustainability 2021, 13, 3990. [CrossRef]

47. Usman, M.; Byrne, J.M.; Chaudhary, A.; Orsetti, S.; Hanna, K.; Ruby, C.; Kappler, A.; Haderlein, S.B. Magnetite and green rust: Synthesis, properties, and environmental applications of mixed-valent iron minerals. Chem. Rev. 2018, 118, 3251-3304. [CrossRef] [PubMed]

48. Zhang, K.; Li, Y.; Wang, Y.; Zhao, J.; Chen, X.; Dai, Y.; Yao, Y. Enhanced electrochemical properties of iron oxalate with more stable $\mathrm{Li}^{+}$ions diffusion channels by controlling polymorphic structure. Chem. Eng. J. 2020, 384, 123281. [CrossRef]

49. ISE. Rare Earth Prices in January 2020. Available online: https://en.institut-seltene-erden.de/preise-fuer-seltene-erden-imjanuar-2020/ (accessed on 28 April 2021).

50. Santoro, R.; Cameselle, C.; Rodrigues-Couto, S.; Sanroman, A. Influence of milk whey, nitrogen and phosphorus concentration on oxalic acid production by Aspergillus Niger. Bioprocess Eng. 1991, 20, 1-5. [CrossRef]

51. Belboom, S.; Szöcs, C.; Léonard, A. Environmental impacts of phosphoric acid production using di-hemihydrate process: A Belgian case study. J. Clean. Prod. 2015, 108, 978-986. [CrossRef]

52. Schmidt, A.; Frydendal, J. Methods for calculating the environmental benefits of 'green' products. In Buying into the Environment, 1st ed.; Erdmenger, C., Ed.; Taylor \& Francis Group: Sheffield, UK, 2003; p. 30.

53. Frischknecht, R.; Braunschweig, A.; Hofstetter, P.; Suter, P. Human health damages due to ionising radiation in life cycle impact assessment. Environ. Impact Assess. Rev. 2000, 20, 159-189. [CrossRef]

54. Charalampides, G.; Vatalis, K.I.; Apostoplos, B.; Ploutarch-Nikolas, B. Rare Earth Elements: Industrial applications and economic dependency of Europe. Procedia Econ. Financ. 2015, 24, 126-135. [CrossRef] 